\title{
Life cycle extension of mobile phones. An exploration with focus on the end-consumer
}

\author{
Odette PENNERS, Janjaap SEMEIJN
}

Maastricht University, The Netherlands

Allard C.R. van RIEL

Hasselt University, Belgium

Wim LAMBRECHTS

Open University of The Netherlands

\begin{abstract}
:
Aim: All mobile phones will eventually become obsolete and should be collected and recycled in order to recover their high content of both dangerous and valuable materials. End-consumers play a key role in these processes as the collection and recycle systems cannot work properly without their contribution. Therefore, this exploratory study investigates how Dutch end-consumers can be stimulated to return their used mobile phones.
\end{abstract}

Design / Research methods: the factors influencing consumers' propensity to return and recycle obsolete mobile phones are examined. The results are based on a survey conducted among endconsumers of mobile phones in the Netherlands.

Conclusions / findings: There is significant recycling potential as the majority of used mobile phones are simply kept at home. Keeping a used phone as a spare phone and being afraid of privacy disclosures are indicated as main reasons for not taking used phones to a recycling point.

Originality / value of the article: The findings indicate that personal satisfaction from recycling and knowledge or awareness of the potential dangers from not properly returning play a crucial role in influencing the propensity.

Keywords: end of life, e-waste, mobile phones, recycling, WEEE

JEL: Q01, Q53, Q56,

Contact details: Wim Lambrechts, Open University of The Netherlands, Postbus 2960, 6401DL Heerlen, The Netherlands. E-mail: wim.lambrechts@ou.nl.

Received: 02.05.2018, 14.09.2018, Revised: 24.04.2018, Accepted: 24.09.2018

Doi: http://dx.doi.org/10.29015/cerem.723 


\section{Introduction}

Today's production of waste from electrical and electronic equipment (WEEE) or "e-waste" amounts to 20-50 million tons every year. With an annual growth rate of $3-5 \%$, it is the fastest growing waste stream in the world (Maragkos et al. 2013). The cell phone industry is one of its major contributors, as cell phones are the most often frequently sold appliances to households (Polák, Drápalová 2012). Worldwide cell phone sales amounted to nearly 1.9 billion units in 2014. Smart phones make up about two-thirds of these global sales (Gartner 2015).

The need for recycling "obsolete" mobile phones has greatly increased. Their usage life cycles, with replacement rates of approximately 18-24 months, are shorter than the designed service life and the highest rates so far in the history of consumer electronic devices (Bask et al. 2013). The major reasons for replacing used mobile phones are unfashionable features or damage to the phone (Yin et al. 2014; YläMella et al. 2015). According to Navazo, Méndez and Peiró (2014), several studies show that $45-48 \%$ of used phones are simply kept at home and 23-30\% are either sold or traded in for a new phone. The number of old mobile phones ending up in recycling facilities differs between studies, ranging from $2 \%$ to $16 \%$ (Navazo et al. 2014).

However, the potential energy and material savings from recycling a larger percentage is substantial, due to the valuable materials (e.g. gold, palladium and silver) present in the mobile phones. They also contain toxic metals such as lead and cadmium, which may create a threat to human health if not properly disposed (Maragkos et al. 2013; Navazo et al. 2014; Speake, Yangke 2015).

Therefore, it is important to know which factors influence consumers' participation in mobile phone waste recycling programs (Baxter, Gram-Hanssen 2016; Borthakur, Govind 2017). According to Tanskanen (2013), a national e-waste management policy requires robust collection and recycling models, as well as awareness and changes in the behavior of the consumer. This paper investigates how end-consumers can be stimulated to return their mobile phones. 


\section{LIFE CYCLE EXTENSION OF MOBILE PHONES}

\section{Literature review and hypotheses}

This section provides a review of the literature and associated hypotheses, covering the life cycle extension of mobile phones, and the factors influencing consumer propensity to recycle.

\subsection{Life cycle extension of mobile phones}

Mobile phones can have many different users during their life span. In the literature, the term life span is not consistent, likewise, the information about the lifespan of mobile phones differs significantly, ranging from 1.5 to 7.0 years (Polák, Drápalová 2012). Other studies mention a potential life span of a mobile phone of about 10 years (Ongondo, Williams 2011a; Nnorom et al. 2009). According to Polák and Drápalová (2012), the life span is the duration of the period in which the good exists in the original form in our society, irrespective whether it still functions.

According to Ongondo and Williams (2011b), collected phones can be processed according to one of the following options: re-use, resell or refurbish. In the case of re-use, the phones are directly donated to other consumers. Reselling to other customers occurs either directly or indirectly through third parties. In the case of refurbishing, there are cleaning and reconditioning steps needed before they can be donated for re-use, resold or exported (Ongondo, Williams 2011b). Nevertheless, many phones never reach one of these options as $45-48 \%$ of used phones are simply kept at home (Navazo et al. 2014; Wilson et al. 2017).

When a mobile phone can no longer be (re)used for its original purpose and becomes waste, it has reached the end of its life. Although legal requirements enforce proper e-waste recycling, illegal export of e-waste to developing countries often takes place and is then deposited in landfills or incinerated (Queiruga et al. 2012; Navazo et al. 2014).

Mobile phones are "up to date" products; they are often replaced before the end of their functional life, due to the rapid introduction of advanced technologies and fashionable features (Cox et al. 2013; Paiano et al. 2013). Frequently, the old phones are stored at home while they may still function. However, after this storage period they might be too old for re-use. Therefore, eliminating the storage period after a 
phone's end-of-first-life can significantly increase the re-use potential (Babbitt et al. 2011).

Designing products that make use of easy-to-reuse models, recyclable materials and renewable resources, or material identifications might be a solution (Babbitt et al. 2011; Bask, Kuula 2011; Kissling et al. 2013). Phones consisting of interchangeable modules provide the convenience of repairing, upgrading and replacing defective parts. End-consumers must still return the replaced components to prevent the same storage problem as with the existing phones.

Another possibility is improving the product service systems in which manufacturers or retailers lease instead of sell mobile phones (Cox et al. 2013). The end-of-first-life management shifts from the consumer to the manufacturer and the phone is less likely to be stored at home. This facilitates the process of closing the loop since the manufacturer owns the product during the entire life cycle and the consumer only pays for the usage (Merkies 2012).

However, leasing does not ensure environmental benefits because the replacement periods for most electronics are shorter than the functional life time (Babbitt et al. 2011). In the case without lease, the consumer determines the moment of acquiring a new phone which typically results in a longer usage period before (NVMP 2016). One option might be the extension of the fixed lease periods which would lower the demand for new phones. Returned phones are older after the extended period, which reduces their resale potential.

Commonly used incentives to return obsolete phones are free envelopes, bags or boxes (Ongondo, Williams 2011b). However, the risk of damage to or loss of the phones sent by post is not guaranteed. Other incentives mentioned by Ongondo and Williams (2011a; 2011b) are charity donations, courier collection, monetary payments, discounts, prize draws, environmental incentives, free airtime/texts, or vouchers. However, large scale surveys among students (Ongondo, Williams 2011a; Li et al. 2012) showed that incentives with a monetary element such as cash payments and vouchers have the greatest influence on the willingness to return mobile phones.

Therefore, serious consideration should be given to deposit refund systems for e-waste recycling as these systems are economically more profitable than other 


\section{LIFE CYCLE EXTENSION OF MOBILE PHONES}

economic incentives such as recycling subsidies, waste disposal fees or taxes on virgin materials (Sabbaghi et al. 2016; Saphores et al. 2012; Ylä-Mella et al. 2015). These deposit refund systems, where consumers get a refund (on the deposit paid at the time of purchase) when they return the product at the end of its useful life, has already become an accepted practice for plastic bottles, glass or newspapers in many countries. According to Tanskanen (2013), similar efficient collection and recycling practices should be established for electronic waste.

However, NVMP (2016) argues that deposit refund systems are expensive and inefficient in order to change consumer behavior. It neither contributes to the responsible processing of e-waste nor to the environment. First, in contrast to for example plastic bottles, electrical devices have a low turnover rate and they are not automatically returned. In order to stimulate consumers financially, a substantial amount of deposit is required. This can have a negative impact on the sales of electronics because the amount is added to the selling price. Consequently, the risk of cross-border shopping increases. Furthermore, manufacturers have to make their products specifically identifiable for the Dutch market. This results in a loss in economies of scale related to higher costs and creates a barrier to the European free market (NVMP 2016). Moreover, practical evidence from Austria and South Korea, which implemented deposit refund systems from 1995 to 2005 and 1992 to 2002 respectively, shows that deposit refund systems on electronics have no significant effects on the return rates (Desmet, Hanquet 2013). Desmet and Hanquet (2013) argue that the monetary amount of the deposit and the collection rate determine the effectiveness of the system. The payment of deposits also requires careful management and monitoring by all the stakeholders involved.

\subsection{Factors influencing return and recycling}

Among the most well-known models to explain human behavior is the theory of planned behavior which is an extension of the theory of reasoned action (Fishbein, Ajzen 1975; Ajzen 1991). The theories assume that human behavior is driven by an individual's motivation to behave in a certain way. According to Ajzen (1991), these motivational factors are called intentions. These intentions are positively related to behavior and formed by the attitude towards the behavior, subjective norms as well 
as (the extended variable) perceived behavioral control (Fishbein, Ajzen 1975; Ajzen 1991). In the recycling literature, behavioral intentions, actual recycling behavior and consumer attitudes towards recycling are also three dependent variables widely used (Hornik et al. 1995). Due to the fact that the differences in correlations of these three variables are not statistically significant, Hornik et al. (1995) suggests to treat them as the one-dimensional construct propensity to recycle.

Hornik et al. (1995) identifies and classifies variables affecting consumers' propensity to recycle in five categories: intrinsic incentives, extrinsic incentives, internal facilitators, external facilitators and a separate group demographic variables. Although there are multiple (as well as overlapping) variables relating to recycling behavior, developing a model including all factors might neither be feasible nor useful as it is too extensive and complex. For that reason, four empirically validated variables that most strongly predict the propensity to recycle are used as a base for this study and where necessary adapted to the situation of obsolete mobile phones (Hornik et al. 1995). These include perceived social influence, personal satisfaction, knowledge and frequency of collections. However, the collection frequency (external facilitator) will be replaced by inconvenience. The reason is that existing ewaste collection systems in the Netherlands mainly consist of central collection points, as opposed to convenient door to door curbside collection such as the waste paper collection in the Netherlands. Therefore, in the current situation of returning mobile phones, the collection frequency is less relevant and will be replaced with the inconvenience to return.

Besides this, monetary incentives will be included because this is an important determinant in order to activate a desired behavior as already became clear from section 2.2.3. It was mentioned that incentives with a monetary element such as cash payments and vouchers have the greatest influence on the willingness to return mobile phones (Ongondo, Williams 2011a; Li et al. 2012).

Moreover, used mobile phones, especially smartphones, contain sensitive personal data that is difficult to fully erase. As a result, end-consumers rather keep their used phones at their end of life instead of selling them to others or return them for recycling. Therefore, the concern about the security of personal data stored in the 


\section{LIFE CYCLE EXTENSION OF MOBILE PHONES}

phone is added to the model as it is a major barrier for returning obsolete phones nowadays (Hobson et al. 2018; Tanskanen 2013).

Furthermore, demographic variables (age, gender, education and income) are included because they are the most commonly investigated variables in the recycling literature, but their effects appear to be inconclusive (Hornik et al. 1995). The following section will shortly explain the conceptualization of the dependent and independent variables before outlining the hypotheses.

\subsection{Analytical framework}

Propensity to return. The dependent variable is the propensity to return. This is based on the study of Hornik et al. (1995) which investigates the critical variables influencing consumers' participation in recycling actions and could be measured by self-reports of behavior or measures of actual behavior.

Although the behavioral intention to return and recycle is an immediate antecedent of behavior and seems a proper measure, the propensity to return will be used in this study. Ajzen (1991: 181) defines intention as "how hard people are willing to try, of how much of an effort they are planning to exert, in order to perform the behavior". However, Davies, Foxall and Pallister's (2002) study mentions that over-reliance on intentions as an indicator for a certain behavior omits the evaluation of the behavior choice being made previous to the actual decision or behavior (e.g. the choice of returning or throwing in the bin). Therefore, it might be more reasonable to try to predict a consumer's propensity to return because it reflects a general willingness to behave in a certain way, whether or not consciously intended to engage in this behavior (Pattaro 2007). In the case of a propensity, an individual is not necessarily committed to act in the suggested manner when a certain condition holds, instead it might also be an input to a further decisional phase in which he or she is likely to behave (Pattaro 2007). On the contrary, in the case of an intention, an individual has made up his or her mind about what to do if a certain situation occurs (e.g. if the phone is at the end of its life, I shall immediately return it). However, returning a mobile phone appears not to be a specific action where consumers systematically intend to engage in at a particular time. Besides this, returning is defined as giving or sending something back. Combining these 
concepts, the propensity to return is defined as the tendency of a consumer to return a mobile phone with the purpose to be properly recycled.

Personal satisfaction from recycling. Carrying out an activity for its inherent satisfaction is an intrinsic factor or motivation (Ryan, Deci 2000; Hornik et al. 1995). Feeling good from pursuing a personally satisfying activity (recycling) might increase the propensity to return mobile phones for recycling. As a consequence, the self-interest to conserve resources in order to achieve personal happiness can lead to direct participation in activities and valued opportunities that make a difference in the end (De Young 2000).

Perceived social influence. While personal satisfaction from recycling relates to the individual's internal incentive to recycle, perceived social influence refers to the impact that external people have on the individual. According to Hornik et al. (1995), social influence can be defined as an individual's concern about the perceptions of others, such as family and friends, if he or she does not recycle. The individual's recycling behavior can be influenced by people in the environment. For example, a consumer might feel obliged to recycle his or her phone if recycling is seen as valuable or is common practice among friends and family.

Knowledge. In general, the more information a person has about recyclable materials or where recyclables are collected the more likely the person will recycle (Schultz et al. 1995). Several studies argue that the promotion of environmental initiatives should be increased to raise consumer awareness of current recycling practices and the importance of mobile phone waste recycling (Jang, Kim 2010; Ongondo, Williams 2011b; Tanskanen 2013; Ylä-Mella et al. 2015). It is necessary to further inform the consumers on the dangers and the potentials concerning electronic waste disposal (Speake, Yangke 2015). Therefore, in this study, knowledge refers to the consumers' awareness regarding the potential threat to the environment and human health from improper disposal.

Monetary rewards. In general, extrinsic incentives such as monetary rewards are successful in order to activate a desired behavior (Hornik et al. 1995). As mentioned before, there are many different incentives to increase the return rate of mobile phones such as free envelopes, discounts, prize draws, and cash payments. However, incentives with a monetary element such as cash payments and vouchers seem to 


\section{LIFE CYCLE EXTENSION OF MOBILE PHONES}

have the greatest influence in order to return mobile phones (Ongondo, Williams 2011a; Li et al. 2012).

Perceived inconvenience. Several studies state that convenience to return is an important factor in whether or not to participate in e-waste recycling activities (Saphores et al. 2012; Tanskanen 2013; Wang et al. 2011). Convenience refers to the consumer's belief of how much effort it takes to return their mobile phones. Existing e-waste collection systems in the Netherlands mainly consist of central collection points, as opposed to convenient door to door curbside collection. These collection points might be considered as more complicated and time consuming as compared to curbside collection. Therefore, in the situation of returning mobile phones, the perceived inconvenience will be measured.

Privacy concern. As mentioned before, the concern for privacy disclosures creates a barrier for returning mobile phones. Besides calling and sending text messages, mobile phones are increasingly used for other purposes. As a consequence, mobile phones contain sensitive personal data which is difficult to completely erase at the end of life. Therefore, end-consumers might be reluctant to sell them to others or return them for recycling.

Demographic factors. Demographic variables (age, gender, educational level and yearly income) are included in the model because they are the most commonly investigated variables in the recycling literature (Hornik et al. 1995; Saphores et al. 2012). However, their effects appear to be inconsistent. End-consumers are individuals with different characteristics and thoughts about for example the residual value or usability of the mobile phone at the end of its life. Therefore a one-size-fitsall approach is not appropriate for e-waste recycling (Speake, Yangke 2015). Hence, the demographic factors age, gender, education and income are expected to have a moderating influence on the propensity to recycle.

The following hypotheses are proposed and will be tested empirically. Consumers who...

H1. feel highly satisfied from recycling are more likely to return and recycle their mobile phones

H2. perceive a high social influence to recycle are more likely to return and recycle mobile phones. 
H3. have knowledge about mobile phone waste recycling are more likely to return and recycle mobile phones.

H4. receive a monetary incentive for returning their phones are more likely to return and recycle mobile phones.

H5. perceive returning their phone as inconvenient are less likely to return and recycle mobile phones.

H6. are concerned about their privacy are less likely to return and recycle mobile phones.

\section{Method}

\subsection{Data collection}

All variables included in this study have been presented in the literature review. Therefore, the items concerning each construct are adopted from previous studies and modified to the current context. The number of items representing a construct and the related sources are presented in the table 1. These constructs consisting of 34 items are measured on a seven-point Likert scale ranging from strongly agree to strongly disagree.

Table 1. Constructs

\begin{tabular}{|l|c|l|}
\hline Construct & Items & \multicolumn{1}{c|}{ Source } \\
\hline Personal satisfaction & 5 & De Young (1985-1986) \\
\hline Social influence & 5 & Lee (2008), Do Valle et al. (2004) \\
\hline Knowledge & 7 & $\begin{array}{l}\text { Davies et al. (2002), Do Valle et al. } \\
(2004)\end{array}$ \\
\hline Monetary rewards & 4 & $\begin{array}{l}\text { Shaw, Maynard (2008), De Young } \\
\text { (1985-1986) }\end{array}$ \\
\hline Inconvenience & 5 & $\begin{array}{l}\text { McCarty, Shrum (1994), Davies et al. } \\
\text { (2002), Do Valle et al. (2004) }\end{array}$ \\
\hline Privacy & 5 & Smith et al. (1996), Malhotra et al. (2004) \\
\hline Propensity to return & 3 & Gursoy et al. (2007) \\
\hline
\end{tabular}




\section{LIFE CYCLE EXTENSION OF MOBILE PHONES}

The survey is distributed among end-consumers of mobile phones in the Netherlands and the unit of analysis are individuals. Convenience sampling is the non-probability sampling technique selected for this study. The primary reason is the ease of obtaining the data from the participants available at a given time (Bickman, Rog 2008). Although this technique restricts the generalization to a wider population, convenience sampling is the preferred technique given the resources available.

Due to the fact of the widespread use and ownership of mobile phones, almost everyone can contribute to this research. Therefore, the participants were kindly requested to forward the questionnaire to other respondents. However, this snowball-sampling might result in a sampling bias which increases the possibility that the participants share the same traits and only a small subgroup of the entire population will be derived (Bickman, Rog 2008). In order to reduce this sampling bias, the survey is distributed among groups with different characteristics in terms of gender and age.

\subsection{Sampling}

In total, 116 participants started the survey. After elimination of incomplete submissions, a total of 101 valid and complete answers could be analyzed. Of these 101 end-consumers, more than half were male (53) and the remaining 48 female. Among the 101 respondents, 60 were categorized into young adults (ages 24 or younger), 23 were middle-aged adults (ages 25-49 years), and 18 were older adults (aged 50 or older). More than two-third of the respondents had a bachelor's degree or higher (68). 45 respondents indicated to earn less than $€ 15.000$ annually, 30 people between $€ 15.000$ and $€ 45.000,12$ people more than $€ 45.000$ and 14 preferred not to answer this question.

As shown in table 2, the respondents own on average 2.90 used mobile phones consisting of 1.61 smartphones and 1.29 standard mobile phones. The average of 2.90 mobile phones per individual in this study is lower than the average of 5 mobile phones as stated by Tanskanen (2013). However, it still represents a large recycling potential and this is confirmed by the fact that the majority of the used mobile phones are simply kept at home (69\%). Keeping the used phone as a spare phone 
and being afraid of privacy disclosures are indicated as the main reasons for not taking the used phones to a recycling point.

The effect of gender, age, education and income on mobile phone ownership and use among the respondents are presented in the Appendix (table A1). It is remarkable that there exists a marginally significant positive linear relationship between income and total average use of mobile phones $(p<0.10)$. This indicates that the use of mobile phones among respondents increases with the incomes earned.

Table 2. Average mobile phone use and ownership among respondents

\begin{tabular}{|l|c|c|c|}
\hline & Average ownership & Average use & Average e-waste \\
\hline Smartphones & 1.61 & 0.97 & 0.64 \\
\hline $\begin{array}{l}\text { Standard mobile } \\
\text { phone }\end{array}$ & 1.29 & 0.19 & 1.10 \\
\hline Total & 2.90 & 1.16 & 1.74 \\
\hline
\end{tabular}

Source: authors' own research.

Moreover, in 29\% of the cases the used mobile phones are re-used: the majority gives them to others $(16 \%)$ or resells them $(11 \%)$, while others leave them at the store when buying a new one $(1 \%)$ or bring them to a recycling point $(1 \%)$. The remaining $2 \%$ dispose them with the mixed waste.

Furthermore, the replacement rate of 18-24 months mentioned in the literature is validated by this research as the majority $(41 \%)$ indicated the same rate for changing to another phone, followed by $24-36$ months (34\%) or less often (18\%). $7 \%$ of the respondents replace their phones every 12-18 months. However, the replacement rates should be interpreted with caution as they often depend on fixed contract periods as in the case of leasing or a phone via work. Therefore it is more important to consider what is done with the used phone after replacing.

\subsection{Measurement model}

The convergent and discriminant validity are examined in order to validate the reflective measurement model. Partial Least Squares (PLS) path modeling with the software tool Smart PLS 3.0 is used for this analysis. PLS can be used for theory 
testing, but it can also be used to indicate whether relationships might or might not exist and to suggest propositions for future testing (Chin 1998). Besides this, PLS is suitable for smaller sample sizes in order to validate a model (Haenlein, Kaplan 2004).

Table 3. Factor loadings, T-values, and composite reliability

\begin{tabular}{|c|c|c|c|c|}
\hline Construct (Composite Reliability) & $\begin{array}{l}\text { Cross } \\
\text { Load. }\end{array}$ & t-value & AVE & $\boldsymbol{\alpha}$ \\
\hline $\begin{array}{l}\text { Inconvenience }(\mathbf{0 . 9 4 8 )} \\
\text { I consider returning and recycling my } \\
\text { used mobile phone as... } \\
\ldots \text { inconvenient } \\
\ldots \text { too much trouble } \\
\ldots \text { too complicated } \\
\ldots \text { too time consuming } \\
\ldots \text { a difficult task }\end{array}$ & $\begin{array}{l}0.866 \\
0.934 \\
0.889 \\
0.863 \\
0.872 \\
\end{array}$ & $\begin{array}{l}9.550 \\
11.938 \\
11.091 \\
13.286 \\
11.468 \\
\end{array}$ & 0.784 & 0.931 \\
\hline $\begin{array}{l}\text { Knowledge (0.893) } \\
\text { Returning used mobile phones with the } \\
\text { purpose to be properly recycled... } \\
\ldots \text { helps to protect the environment } \\
\ldots \text { creates a better environment for future } \\
\text { generations } \\
\ldots \text { is a major way to save energy } \\
\ldots \text { is a major way to reduce pollution } \\
\ldots \text { is a major way to reduce the wasteful } \\
\text { use of land for dumps } \\
\ldots \text { is a major way to conserve valuable } \\
\text { and recyclable materials such as gold, } \\
\text { palladium or silver } \\
\ldots \text { is a major way to help the proper } \\
\text { handling of hazardous and toxic materials, } \\
\text { like lead and cadmium }\end{array}$ & $\begin{array}{l}0.795 \\
0.786 \\
0.689 \\
0.681 \\
0.698 \\
0.692 \\
0.818\end{array}$ & $\begin{array}{l}6.231 \\
6.707 \\
7.633 \\
4.392 \\
7.885 \\
5.995 \\
\\
7.169\end{array}$ & 0.546 & 0.864 \\
\hline $\begin{array}{l}\text { Monetary Rewards (0.909) } \\
\text { I would take recycling my phone more } \\
\text { seriously if I can get a benefit from it } \\
\text { Returning and recycling used mobile } \\
\text { phones is worthwhile if I get cash for it } \\
\text { Returning and recycling used mobile } \\
\text { phones is worthwhile if I get a gift } \\
\text { voucher for future purchases } \\
\text { I would make more of an effort to return } \\
\text { and recycle my phone if I get paid for it }\end{array}$ & $\begin{array}{l}0.870 \\
0.855 \\
0.762 \\
0.889\end{array}$ & $\begin{array}{l}14.693 \\
6.046 \\
5.564 \\
11.176\end{array}$ & 0.715 & 0.871 \\
\hline
\end{tabular}


Odette PENNERS et al.

Table 3. Cont.

\begin{tabular}{|c|c|c|c|c|}
\hline Construct (Composite Reliability) & $\begin{array}{l}\text { Cross } \\
\text { Load. }\end{array}$ & t-value & AVE & $\alpha$ \\
\hline $\begin{array}{l}\text { Privacy (0.931) } \\
\text { Returning used mobile phones causes } \\
\text { serious privacy problems } \\
\text { Compared to others, I am more sensitive } \\
\text { about the way companies handle my } \\
\text { personal information } \\
\text { I am concerned that companies are } \\
\text { collecting too much personal information } \\
\text { about me } \\
\text { I am concerned about threats to my } \\
\text { personal privacy } \\
\text { I keep my used mobile phones to } \\
\text { guarantee my privacy }\end{array}$ & $\begin{array}{l}0.633 \\
0.885 \\
0.946 \\
0.960 \\
0.793\end{array}$ & $\begin{array}{l}1.922 \\
3.713 \\
3.775 \\
3.829 \\
3.012\end{array}$ & 0.726 & 0.931 \\
\hline $\begin{array}{l}\text { Propensity to Return (0.842) } \\
\text { I have the tendency to return and recycle } \\
\text { my mobile phone when it is at the end of } \\
\text { its useful life } \\
\text { I am probably more likely to return and } \\
\text { recycle a mobile phone than most people I } \\
\text { know } \\
\text { I would attempt to notify others if I know } \\
\text { they do not return and recycle their phone }\end{array}$ & $\begin{array}{l}0.795 \\
0.853 \\
0.752\end{array}$ & $\begin{array}{l}13.500 \\
17.277 \\
11.579\end{array}$ & 0.641 & 0.718 \\
\hline $\begin{array}{l}\text { Personal Satisfaction }(\mathbf{0 . 8 5 2}) \\
\text { I try to find ways to avoid the creation of } \\
\text { waste } \\
\text { I rather repair products than throwing } \\
\text { them away } \\
\text { I try to find ways to re-use things again } \\
\text { It feels good seeing more people recycling } \\
\text { I recycle because it feels right }\end{array}$ & $\begin{array}{l}0.738 \\
0.638 \\
\\
0.749 \\
0.754 \\
0.776\end{array}$ & $\begin{array}{l}9.229 \\
5.340 \\
8.061 \\
9.292 \\
10.002\end{array}$ & 0.537 & 0.783 \\
\hline $\begin{array}{l}\text { Social Influence (0.870) } \\
\text { I discuss much about waste recycling and } \\
\text { issues with my friends and family } \\
\text { I share information regarding recycling } \\
\text { with my friends and family frequently } \\
\text { I expect that my family and friends } \\
\text { recycle } \\
\text { My family expects me to recycle } \\
\text { My friends expect me to recycle }\end{array}$ & $\begin{array}{l}0.866 \\
0.824 \\
0.716 \\
0.614 \\
0.750\end{array}$ & $\begin{array}{l}16.338 \\
12.086 \\
6.523 \\
4.044 \\
6.639\end{array}$ & 0.576 & 0.829 \\
\hline
\end{tabular}

Source: authors' own research. 


\section{LIFE CYCLE EXTENSION OF MOBILE PHONES}

For the constructs (latent variables), the loadings of the reflective items are examined in order to determine the appropriateness of the items. Each loading represents the correlation between the item and the related construct (Chin 1998). Hence, items with low loadings imply that they have a weak relationship in terms of shared variance with the construct and should be deleted. In general, items with loadings of less than 0.50 should be dropped (Hulland 1999). All factor loadings resulting from the confirmatory factor analysis exceeded the recommended threshold and were statistically significant (Table 3).

The convergent validity of the measurement model is assessed by calculating the composite reliability (CR), average variance extracted (AVE), and Cronbach's alpha ( $\alpha$ ) as presented in table 3 (Hulland 1999; Fornell, Larcker 1981). The values for both the Cronbach's Alpha and composite reliability are greater than the acceptable standard of 0.70 as suggested by Nunnally (1978). As a result, the reliability or internal consistency of the items that are used to measure a latent construct are sufficient. Furthermore, the average variance extracted (AVE), the average amount of variance in the items that a construct is able to explain, is greater than 0.50 . This indicates that the latent construct explains more than half of its items variances resulting in an adequate internal validity (Fornell, Larcker 1981).

In order to examine the discriminant validity, the criterion suggested by Fornell and Larcker (1981) is applied. Adequate discriminant validity means that the square root of the AVE associated with a specific construct must be greater than its correlations with other constructs. Table 4 shows the descriptive statistics and correlation matrix of the constructs. As shown in table 4, the diagonal elements representing the square root of each AVE are sufficiently greater than the offdiagonal elements in the corresponding rows and columns (Hulland 1999).

As shown in Table 4, the diagonal elements representing the square root of each AVE are sufficiently greater than the off-diagonal elements in the corresponding rows and columns (Hulland, 1999). However, Henseler, Ringle, and Sarstedt (2015) suggest to assess the heterotrait-monotrait ratio (HTMT) of the correlations, which is the average of the heterotrait-heteromethod correlations, relative to the average of the monotrait-heteromethod correlations. Hence, if the HTMT value is below 0.90, 
discriminant validity can be established between two reflective constructs (Henseler et al. 2015).

Table 4. Interconstruct correlations and descriptive statistics

\begin{tabular}{|c|c|c|c|c|c|c|c|c|c|}
\hline Construct & 1 & 2 & 3 & 4 & 5 & 6 & 7 & Mean & $\begin{array}{l}\text { Std. } \\
\text { Dev }\end{array}$ \\
\hline $\begin{array}{l}\text { Inconvenie } \\
\text { nce (1) }\end{array}$ & $0.885^{*}$ & & & & & & & 3.713 & 1.382 \\
\hline $\begin{array}{l}\text { Knowledge } \\
\text { (2) }\end{array}$ & 0.064 & 0.739* & & & & & & 2.371 & 0.761 \\
\hline $\begin{array}{l}\text { Monetary } \\
\text { rewards (3) }\end{array}$ & 0.310 & 0.103 & $0.846^{*}$ & & & & & 2.116 & 0.941 \\
\hline $\begin{array}{l}\text { Personal } \\
\text { satisfaction } \\
\text { (4) }\end{array}$ & -0.138 & 0.082 & -0.072 & 0.733* & & & & 3.034 & 0.958 \\
\hline Privacy (5) & 0.346 & 0.176 & 0.206 & 0.143 & $0.857^{*}$ & & & 3.428 & 1.450 \\
\hline $\begin{array}{l}\text { Propensity } \\
\text { to return } \\
\text { (6) }\end{array}$ & -0.353 & 0.352 & -0.266 & 0.377 & 0.132 & $0.800^{*}$ & & 4.835 & 0.945 \\
\hline $\begin{array}{l}\text { Social } \\
\text { influence } \\
(7)\end{array}$ & -0.074 & 0.254 & -0.045 & 0.560 & 0.161 & 0.431 & $0.759 *$ & 4.687 & 1.082 \\
\hline
\end{tabular}

Source: authors' own research.

Note: *Diagonal elements in the 'correlation of constructs' matrix are the square root of AVE

From Table 5 it is clear that all HTMT values are significantly different from 1 as all the values are below the criterion of 0.90 , and even below the highest standards of 0.85 , indicating sufficient discriminant validity among the constructs used in this study.

In order to test the hypotheses, hierarchical moderated regression analyses (HMRA) was done in SPSS version 22.0. Personal satisfaction, social influence, knowledge, monetary rewards, inconvenience and privacy concern were utilized as independent variables and gender, age, educational level and income as the demographic moderators. 
Table 5. HTMT Results

\begin{tabular}{|l|l|l|l|l|l|l|l|}
\hline Construct & $\mathbf{1}$ & $\mathbf{2}$ & $\mathbf{3}$ & $\mathbf{4}$ & $\mathbf{5}$ & $\mathbf{6}$ & $\mathbf{7}$ \\
\hline Inconvenience (1) & & & & & & & \\
\hline Knowledge (2) & 0.098 & & & & & & \\
\hline Monetary rewards (3) & 0.342 & 0.197 & & & & & \\
\hline Personal satisfaction (4) & 0.215 & 0.233 & 0.159 & & & & \\
\hline Privacy (5) & 0.481 & 0.190 & 0.324 & 0.212 & & & \\
\hline Propensity to return (6) & 0.433 & 0.420 & 0.314 & 0.497 & 0.175 & & \\
\hline Social influence (7) & 0.213 & 0.300 & 0.169 & 0.680 & 0.256 & 0.507 & \\
\hline
\end{tabular}

Source: authors' own research.

\section{Results}

The hypothesized relationships were tested via HMRA using SPSS 22.0. The results are shown in table 6 and in the Appendix (table A2, A3, A4). In order to test the moderating effect of the demographic variables, the first step in HMRA was to test the effects of the main variables on the propensity to return. The results show significant effects of five factors (personal satisfaction: $\beta$ 0.203, $\mathrm{p}<0.05$, knowledge: $\beta 0.412, \mathrm{p}<0.01$, monetary rewards: $\beta-0.219, \mathrm{p}<0.05$, inconvenience: $\beta-0.236, \mathrm{p}<0.001$ and privacy concern: $\beta 0.120, \mathrm{p}<0.10$ ) on the propensity to return, explaining $42.1 \%$ of the variance. Hence, H1 (personal satisfaction), H3 (knowledge), and H5 (inconvenience) are supported. Although, H4 (monetary rewards) and $\mathrm{H6}$ (privacy concern) are significant, they have unexpected coefficients. Therefore, $\mathrm{H} 2$ (social influence: $\beta 0.123$, n.s.), $\mathrm{H} 4$ and $\mathrm{H} 6$ are not supported.

The second step of the HMRA analysis included the full model by adding the moderators to the main model. In order to reduce multicollinearity, these moderators or interaction terms were first mean-centered and then multiplied with each other (Shieh, 2011). The variance inflation factors (VIFs) were calculated in order to test for multicollinearity. Except for the interaction term ( $45.000 \mathrm{x}$ privacy concern), they were all below the threshold of 10 . 
Table 6 shows the moderating effects of gender with female as the baseline. It shows that gender purely moderates the effect of social influence and privacy concern on propensity to return (gender $x$ social influence: $\beta 0.373, p<0.05$, gender $\mathrm{x}$ privacy concern: $\beta-0.353, \mathrm{p}<0.01$ ). Therefore, $\mathrm{H} 2 \mathrm{a}$ (the moderating effect of gender on the relationship between social influence and the propensity to return) and H6a (the moderating effect of gender on the relationship between privacy concern and the propensity to return) are supported, but H1a, H3a, H4a, H5a (the moderating effect of gender on the relationship between personal satisfaction, knowledge, monetary rewards, inconvenience and the propensity to return) are not supported.

Table 6. Moderated regression analysis of the effect of gender

\begin{tabular}{|c|c|c|c|c|}
\hline Constructs & Model 1 & Model 2 & Model 3 & VIF \\
\hline \multicolumn{5}{|l|}{ Independent variables } \\
\hline Personal satisfaction & $0.203 * *$ & $0.206 * *$ & $0.229 *$ & 3.230 \\
\hline Social influence & 0.123 & 0.119 & -0.068 & 3.469 \\
\hline Knowledge & $0.412 * * *$ & $0.402 * * *$ & $0.467 * * *$ & 1.960 \\
\hline Monetary rewards & $-0.219 * *$ & $-0.217 * *$ & $-0.310 * * *$ & 2.586 \\
\hline Inconvenience & $-0.236 * * *$ & $-0.241 * * *$ & $-0.181 * *$ & 2.468 \\
\hline Privacy concern & $0.120 *$ & $0.116^{*}$ & $0.242 * * *$ & 2.179 \\
\hline \multicolumn{5}{|l|}{ Moderating variable } \\
\hline Gender & & -0.062 & -0.107 & 1.301 \\
\hline \multicolumn{5}{|l|}{ Interactions } \\
\hline $\begin{array}{l}\text { Personal satisfaction } \mathrm{x} \\
\text { Gender }\end{array}$ & & & 0.080 & 3.107 \\
\hline Social influence x Gender & & & $0.373 * *$ & 3.370 \\
\hline Knowledge x Gender & & & -0.149 & 2.149 \\
\hline $\begin{array}{l}\text { Monetary rewards } \mathrm{x} \\
\text { Gender }\end{array}$ & & & 0.142 & 2.514 \\
\hline Inconvenience $\mathrm{x}$ Gender & & & -0.118 & 2.600 \\
\hline Privacy concern x Gender & & & $-0.353 * * *$ & 2.796 \\
\hline$R^{2}$ & 0.421 & 0.422 & 0.543 & \\
\hline Adjusted $R^{2}$ & 0.384 & 0.378 & 0.474 & \\
\hline F-value & $11.280 * * *$ & $9.598 * * *$ & $7.849 * * *$ & \\
\hline$\Delta R^{2}$ & - & 0.001 & 0.121 & \\
\hline
\end{tabular}

Source: authors' own research.

$* \mathrm{p}<0.10, * * \mathrm{p}<0.05, * * * \mathrm{p}<0.01$ 


\section{LIFE CYCLE EXTENSION OF MOBILE PHONES}

\section{Discussion}

This study improves the understanding of factors stimulating end-consumers to properly return and recycle their used phones. Personal satisfaction from recycling and knowledge or awareness of the potential dangers from not properly returning and recycling have a significant positive influence. Their strength show the importance of these internal factors influencing the propensity to return. Additionally, their intrinsic nature has a relatively enduring effect on recycling because these can be sustained indefinitely (Hornik et al. 1995). Hence, more information about the toxicity and dangers of e-waste and the potential health impacts of improper disposal should be provided. It is suggested that formal, nonformal and informal learning settings should contribute to increase the mobile phone recycling knowledge and awareness. While this study considers outcome-based knowledge concentrating on global environmental issues, further research might focus on task-related knowledge because this knowledge is also necessary in order to properly recycle. Task related knowledge considers the 'what, where, and how to recycle' knowledge (Davies et al. 2002). However, it was felt that the task-related knowledge was partly captured by respondents' answers 'I do not know where to take the used cell phones' and 'I feel that recycling is troublesome' as important reasons for not taking the used phone to a recycling point.

Inconvenience showed a significant impact: Dutch consumers must bring or send the used phone to a central point. Therefore, methods need to be developed which take the existing infrastructure and resources into account while meeting the needs of end-consumers. Another recommendation is to reduce the inconvenience by decreasing the complexity and effort to return. End-consumers should be better informed about where they can bring or send their used phones as several respondents indicated that they do not know where to take them or find it

troublesome to return. To be more specific, drop-off points in stores, dedicated recycling centers or door to door courier collection are suggestions to increase convenience.

Monetary or financial rewards show an unexpected negative effect on the propensity to return. However, respondents also indicated 'receiving a cash payment 
or gift voucher' as the most important factor that would trigger them to return their used phone. According to Gneezy et al. (2011), monetary rewards result in two types of effects: direct price effect and indirect psychological effect. The psychological effect can sometimes adversely influence the price effect and crowd out the incentivized behaviors. The negative effect can be explained by the respondents' perception of getting not enough money in order to return their phones. In other words, the monetary rewards do not outweigh the efforts or other motivations to return used mobile phones.

Although the respondents further stated 'being afraid of privacy disclosures' as one of the main reasons for not taking used phones to a recycling point, privacy concern is positively related to the propensity to return. A reason for this unexpected positive effect of privacy concerns could be the subjectivity of this factor. Privacy concerns are not absolute concepts as consumers make choices based on trade-offs in which they give up a certain degree of personal information in exchange for benefits (Phelps et al. 2000). It can differ by individual and this is validated in this study because gender, age, education, and income have a significant effect on the relationship between privacy concerns and the propensity to return. Besides the individual characteristics, the type of information and the amount of control consumers have over subsequent distribution are important factors affecting privacy concern (Phelps et al. 2000). In the case of returning mobile phones, end-consumers have full control whether they keep their phone including the personal information or erase and return it.

The insignificance of social influence indicates that there is no overall effect of social influence on propensity to return. There is conflicting evidence whether social norms impact recycling behavior (Davies et al. 2002). Different value systems and cultures among respondents or measurement problems of this factor are possible causes. Hopper and Nielsen (1991) found no direct link between social norms and recycling behavior. Social norms are adopted on a personal level and become personal norms. Thus the direct effect of social influence might be completely mediated through personal norms. The moderated results in this study showed significant cross-over interactions i.e. the effect of social influence on the propensity to return depends on gender, age and income of the respondents. The positive effect 


\section{LIFE CYCLE EXTENSION OF MOBILE PHONES}

of social influence from friends and family on propensity to return is higher among males, middle aged and older adults and people with higher incomes. It is important to take advantage of these differences between individuals in order to design effective recycling programs. Returned phones should provide sufficient refurbishing value to make deposit refund systems economically viable.

Extant literature shows conflicting findings with respect to economic incentives. On the one hand, several researchers state that deposit refund systems for e-waste should be given serious consideration as they are economically more profitable than other economic incentives such as recycling subsidies (Saphores et al. 2012; Tanskanen 2013; Ylä-Mella et al. 2015). On the other hand, deposit refund systems for e-waste are expensive and inefficient, because mobile phones have a relatively lower turnover rate than for example plastic bottles and, due to their small size, consumers do not mind to keep them at home at the end of life. The amount of the deposit and the collection rate determine the outcome of the system. Therefore, respondents were asked what would be the amount of money that would stimulate them to return the used phones through a deposit refund system similar to one for returning plastic bottles. The amount of money ranges from $€ 5$ to $€ 100$ with an average of $€ 30$. However, this amount should be considered with caution as it depends on the type of phone and the extent of damage to the phone, but it gives an initial indication and might be useful for further considerations. Hence, this study not only contributes to earlier studies but might also serve as a starting point for future research. The findings of this research might also be of interest for the return of electronic devices other than cell phones. A similar, more recent problem is created by the booming tablet market, but also very cheap computers on-a-stick, and cameras are a growing source of concern.

Although this study has been conducted with specific attention towards methodological constraints, it has some limitations. The survey response rate leads to issues of generalizability within the Dutch and wider context. However, the results are in line with previous studies (Ylä-Mella et al. 2015; Martinho et al. 2017). 


\section{Conclusion}

Eventually, all mobile phones become obsolete and need to be properly collected in order to recycle their dangerous as well as valuable materials. From economic, ecological and legislative perspectives, this electronic waste should be directed to proper end-of-life processes. The end-consumers have a key role in these processes as the collection and recycle systems cannot work properly without the contribution of these downstream members. They are responsible and have to decide whether to return or keep their mobile phones.

Despite the increase in mobile phone subscriptions, the high replacement rates and the presence of several mobile phone recycling programs in the Netherlands, the return rates are still low. Therefore, this study gathered information about the factors affecting consumers' propensity to participate in mobile phone waste recycling. It can be concluded that personal satisfaction from recycling, awareness and convenience can be improved by providing specific promotions and information regarding mobile phone waste recycling programs. Actions improving the internal facilitators such as educating people and enhancing the social image of mobile phone recycling activities should entice more consumers into phone recycling as well as to continue with this behavior. Recycling needs to be transparent, convenient and rewarding.

\section{References}

Ajzen I. (1991), The theory of planned behavior, „Organizational Behavior and Human Decision Processes”, vol. 50 no. 2, pp. 179-211.

Babbitt C.W., Williams E., Kahhat R. (2011), Institutional disposition and management of end-of-life electronics, „Environmental Science \& Technology”, vol. 45 no. 12, pp. 53665372.

Bask A., Halme M., Kallio M., Kuula M. (2013), Consumer preferences for sustainability and their impact on supply chain management. The case of mobile phones, ,International Journal of Physical Distribution \& Logistics Management”, vol. 43 no. 5/6, pp. 380-406.

Bask A., Kuula M. (2011), Measuring supply chain level environmental sustainability: case Nokia, „International Journal of Business Insights \& Transformation”, vol. 3 no. S3, pp. 1624. 


\section{LIFE CYCLE EXTENSION OF MOBILE PHONES}

Baxter J., Gram-Hanssen I. (2016), Environmental message framing. Enhancing consumer recycling of mobile phones, „Resources, Conservation and Recycling”, vol. 109, pp. 96-101.

Bickman L., Rog D.J. (eds.) (2008), The Sage handbook of applied social research methods, Sage Publications, London.

Borthakur A., Govind M. (2017), Emerging trends in consumers' E-waste disposal behaviour and awareness. A worldwide overview with special focus on India, „Resources, Conservation and Recycling", vol. 117, pp. 102-113.

Chin W.W. (1998), The partial least squares approach to structural equation modeling, „Modern Methods for Business Research”, vol. 295 no. 2, pp. 295-336.

Cox J., Griffith S., Giorgi S., King G. (2013), Consumer understanding of product lifetimes, „Resources, Conservation and Recycling”, vol. 79, pp. 21-29.

Davies J., Foxall G.R., Pallister J. (2002), Beyond the intention-behaviour mythology. An integrated model of recycling, „Marketing Theory”, vol. 2 no. 1, pp. 29-113.

Desmet B., Hanquet G (2013), Rapport „Studie statiegeldsysteem AEEA” Möbius i.o.v. Recupel, https://www.nvmp.nl/uploads/pdf/research/2013\%2005\%2028\%20Studie\%20Statiegeldsyste em\%20AEEA\%20Recupel.pdf [03.11.2018].

De Young R. (1985-1986), Encouraging environmentally appropriate behavior. The role of intrinsic motivation, ,Journal of Environmental Systems”, vol. 15 no. 4, pp. 281-292.

De Young R. (2000), New ways to promote proenvironmental behavior. Expanding and evaluating motives for environmentally responsible behavior, „Journal of Social Issues”, vol. 56 no. 3 , pp. $509-526$.

Do Valle P.O., Reis E., Menezes J., Rebelo E. (2004), Behavioral determinants of household recycling participation the Portuguese case, „Environment and Behavior”, vol. 36 no. 4, pp. 505-540.

Fishbein M., Ajzen I. (1975), Belief, attitude, intention, and behavior. An introduction to theory and research, Addison-Wesley, Boston.

Fornell C., Larcker D. F. (1981), Evaluating structural equation models with unobservable variables and measurement error, „Journal of Marketing Research”, vol. 18 no. 1, pp. 39-50.

Gartner (2015), Gartner says smartphone sales surpassed one billion units in 2014, https://www.gartner.com/newsroom/id/2996817 [03.11.2018]. 
Gneezy U., Meier S., Rey-Biel P. (2011), When and why incentives (don't) work to modify behavior, „The Journal of Economic Perspectives”, vol. 25 no. 4, pp. 191-209.

Gursoy D., McCleary K.W., Lepsito L.R. (2007), Propensity to complain. Effects of personality and behavioral factors. „Journal of Hospitality \& Tourism Research”, vol. 31 no. 3, pp. 358-386.

Haenlein M., Kaplan A.M. (2004), A beginner's guide to partial least squares analysis, „Understanding Statistics”, vol. 3 no. 4, pp. 283-297.

Henseler J., Ringle C.M., Sarstedt M. (2015), A new criterion for assessing discriminant validity in variance-based structural equation modeling, „Journal of the Academy of Marketing Science", vol. 43 no. 1, pp. 115-135.

Hobson K., Lynch N., Lilley D., Smalley G. (2018), Systems of practice and the Circular Economy. Transforming mobile phone product service systems, „Environmental Innovation and Societal Transitions", vol. 26, pp. 147-157.

Hopper J.R., Nielsen J.M. (1991), Recycling as altruistic behavior normative and behavioral strategies to expand participation in a community recycling program, „Environment and Behavior", vol. 23 no. 2, pp. 195-220.

Hornik J., Cherian J., Madansky M., Narayana C. (1995), Determinants of recycling behavior. A synthesis of research results, „The Journal of Socio-Economics”, vol. 24 no. 1, pp. 105-127.

Hulland J., (1999), Use of partial least squares (PLS) in strategic management research. A review of four recent studies, „Strategic Management Journal”, vol. 20 no. 2, pp. 195-204.

Jang Y.C., Kim M. (2010), Management of used \& end-of-life mobile phones in Korea. A review, „Resources, Conservation and Recycling”, vol. 55 no. 1, pp. 11-19.

Kissling R., Coughlan D., Fitzpatrick C., Boeni H., Luepschen C., Andrew S., Dickenson J. (2013), Success factors and barriers in re-use of electrical and electronic equipment, „Resources, Conservation and Recycling”, vol. 80, pp. 21-31.

Lee K. (2008), Opportunities for green marketing: young consumers. „Marketing Intelligence \& Planning", vol. 26 no. 6, pp. 573-586.

Li B., Yang J., Song X., Lu B. (2012), Survey on disposal behaviour and awareness of mobile phones in Chinese university students, „Procedia Environmental Sciences”, vol. 16, pp. 469-476.

Malhotra N.K., Kim S.S., Agarwal J. (2004), Internet users' information privacy concerns (IUIPC). The construct, the scale, and a causal model, „Information Systems Research”, vol. 15 no. 4 , pp. 336-355. 


\section{LIFE CYCLE EXTENSION OF MOBILE PHONES}

Maragkos K.G., Hahladakis J.N., Gidarakos E. (2013), Qualitative and quantitative determination of heavy metals in waste cellular phones, „Waste Management”, vol. 33 no. 9 , pp. 1882-1889.

Martinho G., Magalhães D., Pires A. (2017), Consumer behavior with respect to the consumption and recycling of smartphones and tablets. An exploratory study in Portugal, „Journal of Cleaner Production”, vol. 156, pp. 147-158.

McCarty J.A., Shrum L.J. (1994), The recycling of solid wastes. Personal values, value orientations, and attitudes about recycling as antecedents of recycling behavior, „Journal of Business Research”, vol. 30 no. 1, pp. 53-62.

Merkies J. (2012), The lease society. The end of ownership, Cross Media Printing Unit, Brussel.

Navazo J.M.V., Méndez G.V., Peiró L.T. (2014), Material flow analysis and energy requirements of mobile phone material recovery processes, „The International Journal of Life Cycle Assessment”, vol. 19 no. 3, pp. 567-579.

Nnorom I.C., Ohakwe J., Osibanjo O. (2009), Survey of willingness of residents to participate in electronic waste recycling in Nigeria. A case study of mobile phone recycling, „Journal of Cleaner Production”, vol. 17 no. 18, pp. 1629-1637.

Nunnally J.C. (1978), Psychometric theory, 2nd ed., McGraw-Hill, New York.

NVMP (2016), http://www.nvmp.nl/ [17.05.2016].

Ongondo F.O., Williams I.D. (2011a), Greening academia. Use and disposal of mobile phones among university students, „Waste Management”, vol. 31 no. 7, pp. 1617-1634.

Ongondo F.O., Williams I.D. (2011b), Mobile phone collection, reuse and recycling in the UK, „Waste Management”, vol. 31 no. 6, pp. 1307-1315.

Paiano A., Lagioia G., Cataldo A. (2013), A critical analysis of the sustainability of mobile phone use, „Resources, Conservation and Recycling”, vol. 73, pp. 162-171.

Pattaro E. (ed.) (2007), A treatise of legal philosophy and general jurisprudence. Vol. 1: The law and the right, Vol. 2: Foundations of law, Vol. 3: Legal institutions and the sources of law, Vol. 4: Scienta juris, legal doctrine as knowledge of law and as a source of law, Vol. 5: Legal reasoning, a cognitive approach to the law, Springer Science \& Business Media, The Hague.

Phelps J., Nowak G., Ferrell E. (2000), Privacy concerns and consumer willingness to provide personal information, ,Journal of Public Policy \& Marketing”, vol. 19 no. 1, pp. 2741. 
Polák M., Drápalová L. (2012), Estimation of end of life mobile phones generation. The case study of the Czech Republic, „Waste Management”, vol. 32 no. 8, pp. 1583-1591.

Queiruga D., Benito J.G., Lannelongue G. (2012), Evolution of the electronic waste management system in Spain, „Journal of Cleaner Production”, vol. 24, pp. 56-65.

Ryan R.M., Deci E.L. (2000), Intrinsic and extrinsic motivations. Classic definitions and new directions, „Contemporary Educational Psychology”, vol. 25 no. 1, pp. 54-67.

Sabbaghi M., Behdad S., Zhuang J. (2016), Managing consumer behavior toward on-time return of the waste electrical and electronic equipment. A game theoretic approach, „International Journal of Production Economics”, vol. 182, pp. 545-563.

Saphores J.D.M., Ogunseitan O.A., Shapiro A.A. (2012), Willingness to engage in a proenvironmental behavior. An analysis of e-waste recycling based on a national survey of US households, „Resources, Conservation and Recycling”, vol. 60, pp. 49-63.

Schultz P.W., Oskamp S., Mainieri T. (1995), Who recycles and when? A review of personal and situational factors, „Journal of Environmental Psychology”, vol. 15 no. 2, pp. 105-121.

Shaw P.J., Maynard S.J. (2008), The potential of financial incentives to enhance householders' kerbside recycling behavior, ,Waste Management”, vol. 28 no. 10, pp. 17321741.

Shieh G. (2011), Clarifying the role of mean centring in multicollinearity of interaction effects, „British Journal of Mathematical and Statistical Psychology”, vol. 64 no. 3, pp. 462477.

Smith H.J., Milberg S.J., Burke S.J. (1996), Information privacy. Measuring individuals' concerns about organizational practices, „MIS Quarterly”, vol. 20 no. 2, pp. 167-196.

Speake J., Yangke L.N. (2015), ,What do I do with my old mobile phones? I just put them in a drawer". Attitudes and perspectives towards the disposal of mobile phones in Liverpool, UK, „Human Geographies-Journal of Studies \& Research in Human Geography”, vol. 9 no. 2, pp. 241-260.

Subramanian N., Gunasekaran A. (2015), Cleaner supply-chain management practices for twenty-first-century organizational competitiveness. Practice-performance framework and research propositions, „International Journal of Production Economics”, vol. 164, pp. 216233.

Tanskanen P. (2013), Management and recycling of electronic waste, „Acta Materialia”, vol. 61 no. 3, pp. 1001-1011. 


\section{LIFE CYCLE EXTENSION OF MOBILE PHONES}

Wang Z., Zhang B., Yin J., Zhang X. (2011), Willingness and behavior towards e-waste recycling for residents in Beijing city, China, ,Journal of Cleaner Production”, vol. 19 no. 9 , pp. 977-984.

Wilson, G. T., Smalley, G., Suckling, J. R., Lilley, D., Lee, J., Mawle, R. (2017), The hibernating mobile phone: Dead storage as a barrier to efficient electronic waste recovery, „Waste Management”, vol. 60, pp. 521-533.

Yin J., Gao Y., Xu H. (2014), Survey and analysis of consumers' behaviour of waste mobile phone recycling in China, ,Journal of Cleaner Production”, vol. 65, pp. 517-525.

Ylä-Mella J., Keiski R.L., Pongrácz E. (2015), Electronic waste recovery in Finland. Consumers' perceptions towards recycling and re-use of mobile phones, „Waste Management", vol. 45, pp. 374-384. 
Odette PENNERS et al.

\section{APPENDIX}

Table A1. Mobile phone ownership and use among respondents

\begin{tabular}{|c|c|c|c|c|c|c|c|c|c|c|}
\hline & \multicolumn{3}{|c|}{ Average ownership } & \multicolumn{3}{|c|}{ Average use } & \multicolumn{3}{|c|}{ Average e-waste } & \multirow{2}{*}{$\begin{array}{c}\text { To } \\
\text { t. } \\
\text { res } \\
\text { p. }\end{array}$} \\
\hline & $\begin{array}{c}\text { Smar } \\
\mathrm{t}- \\
\text { phon } \\
\mathrm{e} \\
\end{array}$ & $\begin{array}{c}\text { Stand } \\
\text { ard }\end{array}$ & $\begin{array}{c}\text { Tota } \\
1\end{array}$ & $\begin{array}{c}\text { Smart } \\
- \\
\text { phone }\end{array}$ & $\begin{array}{c}\text { Stand } \\
\text { ard }\end{array}$ & Total & $\begin{array}{c}\text { Smar } \\
\text { t- } \\
\text { phon } \\
\text { e } \\
\end{array}$ & $\begin{array}{c}\text { Stand } \\
\text { ard }\end{array}$ & Total & \\
\hline \multicolumn{11}{|l|}{ Gender } \\
\hline Male & 1.66 & 1.47 & 3.13 & 0.96 & 0.26 & 1.22 & 0.70 & 1.21 & 1.91 & 53 \\
\hline Female & 1.57 & 1.08 & 2.65 & 0.98 & 0.10 & 1.08 & 0.59 & 0.98 & 1.57 & 48 \\
\hline \multicolumn{11}{|l|}{ Age } \\
\hline$\leq 24$ & 1.73 & 1.10 & 2.83 & 1.00 & 0.10 & 1.10 & 0.73 & 1.00 & 1.73 & 60 \\
\hline $25-49$ & 1.83 & 1.57 & 3.40 & 1.00 & 0.17 & 1.17 & 0.83 & 1.40 & 2.23 & 23 \\
\hline$\geq 50$ & 0.94 & 1.56 & 2.50 & 0.83 & 0.50 & 1.33 & 0.11 & 1.06 & 1.17 & 18 \\
\hline \multicolumn{11}{|c|}{ Educational level } \\
\hline $\begin{array}{l}\text { Sec.(vo } \\
\text { c) } \\
\text { educati } \\
\text { on }\end{array}$ & 1.30 & 1.30 & 2.60 & 0.91 & 0.30 & 1.21 & 0.39 & 1.00 & 1.39 & 33 \\
\hline $\begin{array}{c}\text { Higher } \\
\text { educati } \\
\text { on }\end{array}$ & 1.76 & 1.28 & 3.04 & 1.00 & 0.13 & 1.13 & 0.76 & 1.15 & 1.91 & 68 \\
\hline \multicolumn{11}{|c|}{ Annual income } \\
\hline$<€ 15 \mathrm{k}$ & 1.76 & 1.11 & 2.87 & 0.98 & 0.09 & 1.07 & 0.78 & 1.02 & 1.80 & 45 \\
\hline $\begin{array}{c}€ 15 \mathrm{k}- \\
45 \mathrm{k}\end{array}$ & 1.70 & 1.40 & 3.10 & 1.00 & 0.20 & 1.20 & 0.70 & 1.20 & 1.90 & 30 \\
\hline$>€ 45 \mathrm{k}$ & 1.33 & 1.83 & 3.16 & 1.00 & 0.42 & 1.42 & 0.33 & 1.41 & 1.74 & 12 \\
\hline n.a. & 1.21 & 1.14 & 2.35 & 0.86 & 0.29 & 1.15 & 0.35 & 0.85 & 1.20 & 14 \\
\hline
\end{tabular}

Source: authors' own research. 
Table A2. Moderated regression analysis of the effect of age

\begin{tabular}{|c|c|c|c|c|}
\hline Constructs & Model 1 & Model 2 & Model 3 & VIF \\
\hline \multicolumn{5}{|l|}{ Independent variables } \\
\hline Personal satisfaction & $0.203 * *$ & $0.162 *$ & 0.184 & \multirow{6}{*}{$\begin{array}{l}2.629 \\
2.734 \\
1.600 \\
2.159 \\
2.068 \\
2.061\end{array}$} \\
\hline Social influence & 0.123 & $0.144^{*}$ & -0.054 & \\
\hline Knowledge & $0.412 * * *$ & $0.362 * * *$ & $0.346^{* * *}$ & \\
\hline Monetary rewards & $-0.219 * *$ & $-0.224 * *$ & $-0.267 * *$ & \\
\hline Inconvenience & $-0.236 * * *$ & $-0.241 * * *$ & $-0.172 * *$ & \\
\hline Privacy concern & $0.120 *$ & $0.113 *$ & $0.175^{* *}$ & \\
\hline \multicolumn{5}{|l|}{ Moderating variable } \\
\hline $\begin{array}{l}25-49 \\
\geq 50\end{array}$ & & $\begin{array}{l}-0.143 \\
-0.006 \\
\end{array}$ & $\begin{array}{l}-0.168 \\
-0.087 \\
\end{array}$ & $\begin{array}{l}2.281 \\
2.243 \\
\end{array}$ \\
\hline \multicolumn{5}{|l|}{ Interactions } \\
\hline $\begin{array}{l}\text { Personal satisfaction } \mathrm{x} \\
25-49\end{array}$ & & & \multirow{4}{*}{$\begin{array}{l}-0.052 \\
0.400 * \\
-0.190 \\
0.027\end{array}$} & \multirow{4}{*}{$\begin{array}{l}1.827 \\
2.054 \\
2.127 \\
2.446\end{array}$} \\
\hline Social influence x 25-49 & & & & \\
\hline Knowledge x 25-49 & & & & \\
\hline $\begin{array}{l}\text { Monetary rewards x 25- } \\
49\end{array}$ & & & & \\
\hline Inconvenience x 25-49 & & & \multirow{8}{*}{$\begin{array}{l}-0.364 * \\
0.184 \\
-0.003 \\
\\
0.565 * * \\
0.070 \\
0.039 \\
0.279 \\
-0.589 * * *\end{array}$} & \multirow{8}{*}{$\begin{array}{l}2.962 \\
5.638 \\
2.490 \\
\\
3.691 \\
2.302 \\
1.761 \\
3.605 \\
4.039\end{array}$} \\
\hline Privacy concern $x$ 25-49 & & & & \\
\hline $\begin{array}{l}\text { Personal satisfaction } \mathrm{x} \geq \\
50\end{array}$ & & & & \\
\hline Social influence $\mathrm{x} \geq 50$ & & & & \\
\hline Knowledge $x \geq 50$ & & & & \\
\hline Monetary rewards $\mathrm{x} \geq 50$ & & & & \\
\hline Inconvenience $\mathrm{x} \geq 50$ & & & & \\
\hline Privacy concern $x \geq 50$ & & & & \\
\hline$R^{2}$ & 0.421 & 0.421 & 0.566 & \\
\hline Adjusted $R^{2}$ & 0.384 & 0.370 & 0.458 & \\
\hline F-value & $11.280 * * *$ & $8.352 * * *$ & $5.220 * * *$ & \\
\hline$\Delta R^{2}$ & - & - & 0.145 & \\
\hline
\end{tabular}

Source: authors' own research.

$* \mathrm{p}<0.10, * * \mathrm{p}<0.05, * * * \mathrm{p}<0.01$ 
Odette PENNERS et al.

Table A3. Moderated regression analysis of the effect of educational level

\begin{tabular}{|c|c|c|c|c|}
\hline Constructs & Model 1 & Model 2 & Model 3 & VIF \\
\hline \multicolumn{5}{|l|}{ Independent variables } \\
\hline Personal satisfaction & $0.203^{* *}$ & \multirow{7}{*}{$\begin{array}{l}0.164 * \\
0.143^{*} \\
0.377^{* * *} \\
-0.234 * * * \\
-0.228^{* * *} \\
0.121^{*}\end{array}$} & \multirow{7}{*}{$\begin{array}{l}0.163 \\
0.037 \\
0.283 \\
-0.278^{* *} \\
-0.187^{*} \\
-0.048\end{array}$} & \multirow{7}{*}{$\begin{array}{l}4.201 \\
3.742 \\
4.224 \\
3.094 \\
3.319 \\
3.977\end{array}$} \\
\hline Social influence & 0.123 & & & \\
\hline Knowledge & $0412 * * *$ & & & \\
\hline & & & & \\
\hline Monetary rewards & $-0.219 * *$ & & & \\
\hline Inconvenience & $-0.236 * * *$ & & & \\
\hline Privacy concern & $0.120^{*}$ & & & \\
\hline \multicolumn{5}{|l|}{ Moderating variable } \\
\hline Higher education & & 0.108 & 0.100 & 1.075 \\
\hline \multicolumn{5}{|l|}{ Interactions } \\
\hline $\begin{array}{l}\text { Personal satisfaction } x \text { High } \\
\text { edu }\end{array}$ & & & \multirow{6}{*}{$\begin{array}{l}0.108 \\
0.156 \\
0.153 \\
-0.002 \\
\\
-0.019 \\
0.238^{*}\end{array}$} & \multirow{6}{*}{$\begin{array}{l}3.604 \\
3.456 \\
\\
3.983 \\
3.128 \\
\\
3.219 \\
4.058\end{array}$} \\
\hline Social influence x High edu & & & & \\
\hline Knowledge $\mathrm{x}$ High edu & & & & \\
\hline Monetary rewards x High & & & & \\
\hline $\begin{array}{l}\text { edu } \\
\text { Inconvenience } \mathrm{x} \text { High edu }\end{array}$ & & & & \\
\hline \multicolumn{3}{|l|}{ Privacy concern x High edu } & & \\
\hline$R^{2}$ & 0.421 & 0.421 & 0.478 & \\
\hline Adjusted $R^{2}$ & 0.384 & 0.376 & 0.400 & \\
\hline F-value & $11.280 * * *$ & $9.618 * * *$ & $6.120 * * *$ & \\
\hline$\Delta R^{2}$ & - & - & 0.058 & \\
\hline
\end{tabular}

Source: authors' own research.

$* \mathrm{p}<0.10, * * \mathrm{p}<0.05, * * * \mathrm{p}<0.01$ 
Table A4. Moderated regression analysis of the effect of annual income

\begin{tabular}{|c|c|c|c|c|}
\hline Constructs & Model 1 & Model 2 & Model 3 & VIF \\
\hline \multicolumn{5}{|l|}{ Independent variables } \\
\hline Personal satisfaction & $0.203 * *$ & \multirow{6}{*}{$\begin{array}{l}0.205^{* *} \\
0.090 \\
0.451 * * * \\
-0.215^{* *} \\
-0.234 * * * \\
0.113^{*}\end{array}$} & \multirow{6}{*}{$\begin{array}{l}0.363 * * \\
-0.206 * \\
0.480 * * * \\
-0.240 * * \\
-0.192 * * \\
0.166 * *\end{array}$} & \multirow{6}{*}{$\begin{array}{l}3.827 \\
3.726 \\
2.319 \\
2.387 \\
2.561 \\
2.388\end{array}$} \\
\hline Social influence & 0.123 & & & \\
\hline Knowledge & $0.412 * * *$ & & & \\
\hline Monetary rewards & $-0.219 * *$ & & & \\
\hline Inconvenience & $-0.236 * * *$ & & & \\
\hline Privacy concern & $0.120^{*}$ & & & \\
\hline \multicolumn{5}{|l|}{ Moderating variable } \\
\hline $\begin{array}{l}€ 15.001-€ 45.000 \\
>€ 45,001 \\
\text { n.a. }\end{array}$ & & $\begin{array}{l}0.183 \\
-0.116 \\
-0.190\end{array}$ & $\begin{array}{l}0.059 \\
-0.374 \\
-0.213\end{array}$ & $\begin{array}{l}1.532 \\
1.870 \\
3.241\end{array}$ \\
\hline \multicolumn{5}{|l|}{ Interactions } \\
\hline $\begin{array}{l}\text { Personal satisfaction } x \text { 15.001- } \\
45.000\end{array}$ & & & \multirow{4}{*}{$\begin{array}{l}-0.157 \\
0.428 * * \\
-0.349 \\
0.043\end{array}$} & 1.965 \\
\hline $\begin{array}{l}\text { Social influence x } 15.001- \\
45.000\end{array}$ & & & & 1.885 \\
\hline Knowledge x 15.001- 45.000 & & & & 1.778 \\
\hline $\begin{array}{l}\text { Monetary rewards x } 15.001- \\
45.000\end{array}$ & & & & 1.808 \\
\hline $\begin{array}{l}\text { Inconvenience x 15.001- } \\
45.000\end{array}$ & & & $\begin{array}{l}0.375^{*} \\
-0.366^{* *}\end{array}$ & $\begin{array}{l}3.484 \\
3.414\end{array}$ \\
\hline $\begin{array}{l}\text { Privacy concern x } 15.001- \\
45.000\end{array}$ & & & -0.117 & 1.875 \\
\hline $\begin{array}{l}\text { Personal satisfaction } \mathrm{x}> \\
45,001\end{array}$ & & & $\begin{array}{l}0.641 * * \\
-0.370\end{array}$ & $\begin{array}{l}2.313 \\
4.864\end{array}$ \\
\hline Social influence $\mathrm{x}>45,001$ & & & 0.128 & 4.291 \\
\hline Knowledge $\mathrm{x}>45,001$ & & & $-0.501 * *$ & 2.244 \\
\hline Monetary rewards $\mathrm{x}>45,001$ & & & -0.149 & 8.789 \\
\hline Inconvenience $\mathrm{x}>45,001$ & & & $0.911 * *$ & 10.09 \\
\hline Personal satisfaction x n.a. & & & -0.193 & 1.884 \\
\hline Social influence $\mathrm{x}$ n.a. & & & 0.348 & $\begin{array}{l}3.118 \\
3.408\end{array}$ \\
\hline Knowledge x n.a. & & & $\begin{array}{l}0.352 * \\
-0550 * *\end{array}$ & $\begin{array}{l}3.408 \\
3.344\end{array}$ \\
\hline Monetary rewards x n.a. & & & & \\
\hline Inconvenience x n.a. & & & & \\
\hline Privacy concern x n.a. & & & & \\
\hline$R^{2}$ & 0.421 & 0.438 & 0.615 & \\
\hline Adjusted $R^{2}$ & 0.384 & 0.382 & 0.478 & \\
\hline F-value & $11.280 * * *$ & $7.785 * * *$ & $4.493 * * *$ & \\
\hline$\Delta R^{2}$ & - & 0.017 & 0.178 & \\
\hline
\end{tabular}

Source: authors' own research.

$* \mathrm{p}<0.10, * * \mathrm{p}<0.05, * * * \mathrm{p}<0.01$ 